\title{
GNG2 wt Allele
}

National Cancer Institute

\section{Source}

National Cancer Institute. GNG2 wt Allele. NCI Thesaurus. Code C114329.

Human GNG2 wild-type allele is located in the vicinity of $14 q 21$ and is approximately 153

$\mathrm{kb}$ in length. This allele, which encodes guanine nucleotide-binding protein $\mathrm{G}(\mathrm{I}) / \mathrm{G}(\mathrm{S}) / \mathrm{G}(\mathrm{O})$

subunit gamma-2 protein, is involved in G protein-dependent signal transduction. 